\title{
More intensive ice melting and turbulent exchange under the ice in the areas of the jet-like currents on Lake Baikal
}



\author{
Aslamov I.A. ${ }^{1 *}$, Granin N.G. ${ }^{1}$, Zyryanov V.N. ${ }^{2}$ \\ ${ }^{1}$ Limnological Institute, Siberian Branch of the Russian Academy of Sciences, Ulan-Batorskaya Str., 3, Irkutsk, 664033, Russia \\ ${ }^{2}$ Water Problems Institute, Russian Academy of Sciences, Gubkina Str. 3, Moscow, 119333, Russia
}

\begin{abstract}
This study discusses the areas with decreased ice thickness detected by satellite images in the late March-early April before the destruction of ice. We compared the areas of jet-like currents near Kadilny Cape with ring structures on the ice. The data on the measurements of the ice thickness and currents in these areas indicate that a decrease in the ice thickness is due to the intensification of under-ice currents. Also we estimated heat fluxes at the ice-water interface for these areas.
\end{abstract}

Keywords: Lake Baikal, ice cover, ice ring structures, currents.

The existence of jet-like currents (areas of decreasing thickness and early destruction of ice) on Lake Baikal is well-known and has been described in numerous studies. The occurrence of jet-like currents was often associated with gas discharge from the bottom sediments (Tsurikov, 1939; Verbolov et al., 1965). Currently, it has been revealed that a decrease in the ice thickness can be associated with both the rise of water masses caused by the emersion of gas bubbles (Tsurikov, 1939) and intensification of underice currents (Kirillin et al., 2020).

Satellite images allow obtaining the previously unavailable information about the state of ice throughout the area of Lake Baikal. The process of ice destruction begins with the formation of small needlelike crystals in the upper layer. When the water appears on the surface, the ice quickly decays throughout its thickness; the water goes downwards through capillary channels, and the ice is impregnated with water like a sponge (Verbolov et al., 1965). At this time, a dark area appears in satellite images, where the ice thickness is less than in the surrounding area, and the water level in microcracks is closer to the surface of the ice. An analysis of satellite images indicated more than 50 ice ring formations on Lake Baikal since 1969 (Granin et al., 2015; 2018; Kouraev et al., 2016; 2019). Study of field research data revealed that ice ring structures form due to circle anticyclonic currents under the ice. Moreover, the radius of the ring is close to the baroclinic Rossby radius of deformation (Granin et al., 2015; 2018; Kouraev et al., 2016).

In 2016, comprehensive studies were conducted on the dynamics of the ice thickness and heat transfer at the ice-water interface at two stations in Southern
Baikal (Aslamov et al., 2017). Station 1 was installed $8 \mathrm{~km}$ from the Tankhoy settlement, in the area with background velocities of currents. Station 2 was located $4 \mathrm{~km}$ from the Bolshiye Koty settlement, in the area with relatively high velocities of under-ice currents (Fig.). The measured values of air temperature and incoming solar radiation were almost the same for both stations. Average velocities of under-ice currents at station 1 were approximately $1-4 \mathrm{~cm} / \mathrm{s}$, whereas at station 2, their values varied from 6 to $10 \mathrm{~cm} / \mathrm{s}$. Despite the similar meteorological conditions, the dynamics of change in the ice thickness at the two stations fundamentally differed (inset in Fig.). Starting with almost the same thickness as at station 1, the ice at station 2 increased much slower, stopping several times, and since the early March, the ice began to melt. This is primarily due to the more intensive currents at this station. The result was a thawed patch in ice that has formed by the late March along the northwestern shore of the lake, passed through station 2, and could be clearly seen in satellite images (Fig.).

The figure indicates that the color of the ice in the thawed patch is comparable with the color of the ice in the dark part of the ice ring structure that appeared at that time near Nizhneye Izgolovie Cape of the Svyatoy Nos Peninsula. The difference in the ice thickness between the background station 1 and the station near the thawed patch at the end of March was $25 \mathrm{~cm}$ (inset in Fig.). This is comparable with the difference in the ice thickness between the centre and periphery of the ring structure near Nizhneye Izgolovie Cape $(24-32 \mathrm{~cm}$ according to Kouraev et al., 2019) as well as the ring structure studied in 2009 near the Kultuk settlement (27-31 cm according to Granin et al., 2015; 2018).

*Corresponding author.

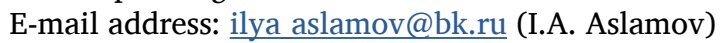




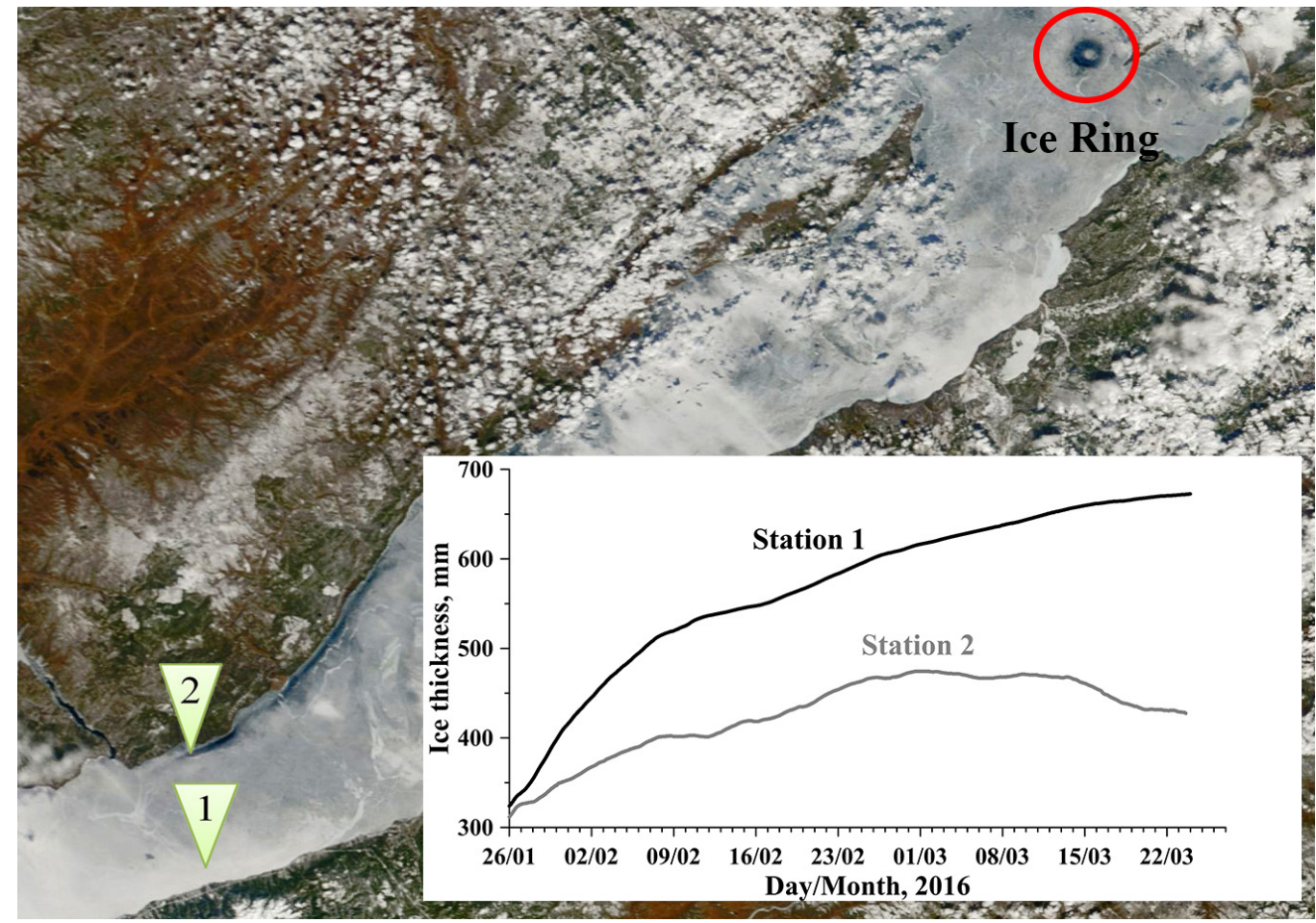

Fig. Location of the measurement stations and the ice situation in Southern and Central Baikal on 4 April 2016; the inset shows the dynamics of the ice thickness at the stations.

Taking into account the comparable difference in the currents velocities between station 1 and station 2, as well as between the center and periphery of the ring structure (Granin et al., 2015; 2018), we can conclude that heat flux from water to ice near the thawed patch and directly in the ice ring has one order and, according to our calculations, equals to $20-40 \mathrm{~W} / \mathrm{m}^{2}$. By contrast, near the background station 1 , the values of the heat flux at the water-ice interface ranged from 2 to $15 \mathrm{~W} /$ $\mathrm{m}^{2}$. This suggests that under-ice currents are the main cause of an increase in the heat flux at the water-ice interface and, thus, they contribute to more intensive ice thawing in spring and formation of ring structures.

This study was carried out within the framework of the LIN SB RAS State Task No. 0345-2019-0008 and supported by RFBR (Grant No. 19-05-00522).

\section{References}

Aslamov I.A., Kozlov V.V., Kirillin G.B. et al. 2017. A study of heat transport at the ice base and structure of the under-ice water layer in Southern Baikal. Water Resources 44: 428-441. DOI: 10.1134/S0097807817030034

Granin N.G., Kozlov V.V., Tsvetova E.A. et al. 2015. Field studies and some results of numerical modeling of a ring structure on Baikal ice. Doklady Earth Sciences 461: 316-320. DOI: 10.1134/S1028334X15030204

Granin N.G., Mizandrontsev I.B., Kozlov V.V. et al. 2018. Natural ring structures on the Baikal ice cover: analysis of experimental data and mathematical modeling. Russian Geology and Geophysics 59: 1514-1525. DOI: 10.1016/j. rgg.2018.10.011

Kirillin G., Aslamov I., Kozlov V. et al. 2020. Turbulence in the stratified boundary layer under ice: observations from Lake Baikal and a new similarity model. Hydrology and Earth System Sciences 24: 1691-1708. DOI: 10.5194/ hess-24-1691-2020

Kouraev A.V., Zakharova E.A., Rémy F. et al. 2016. Giant ice rings on lakes Baikal and Hovsgol : inventory, associated water structure and potential formation mechanism. Limnology and Oceanography 61: 1001-1014. DOI: 10.1002/ lno.10268

Kouraev A.V., Zakharova E.A., Rémy F. et al. 2019. Giant ice rings on lakes and field observations of lens-like eddies in the Middle Baikal (2016-2017). Limnology and Oceanography 64: 2738-2754. DOI: 10.1002/lno.11338

Tsurikov V.L. 1939. Nablyudeniya nad ledyanym pokrovom yuzhnogo Baikala v 1934 g. Nekotoryye zamechaniya otnositelno formul narastaniya ledyanogo pokrova [Observations on the ice cover of Southern Baikal in 1934. Some comments on the formulas of the increase in ice cover]. Trudy Baikalskoy Limnologicheskoy Statsii [Proceedings of the Baikal Limnological Station] 9: 23-43. (in Russian)

Verbolov V.I., Sokolnikov V.M., Shimaraev M.N. 1965. Gidrometeorologicheskiy rezhim i teplovoy balans ozera Baikal [Hydrometeorological regime and heat balance of Lake Baikal]. Moscow: Nauka. (in Russian) 